ISSN [E]: 2477-0515 ISSN [P]: 2339-0794

DOI: $10.26858 /$ jnp.v9i1.20228

Online: https://ojs.unm.ac.id/nalar

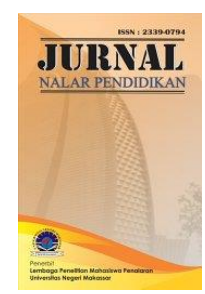

\title{
PENERAPAN MEDIA PEMBELAJARAN QR CODE BERBANTUAN CANVA UNTUK MENINGKATKAN HASIL BELAJAR AKUNTANSI
}

\author{
Susi Agustini \\ Guru SMA Negeri 1 Besuki Situbondo \\ susismabes@gmail.com
}

\begin{abstract}
Abstrak
Penelitian ini bertujuan untuk mengkaji penerapan media pembelajaran $Q R$ Code berbantuan Canva dalam meningkatkan hasil belajar siswa kelas XII IPS 2 SMA Negeri 1 Besuki pada mata pelajaran akuntansi. Penelitian ini merupakan penelitian tindakan kelas (classroom action research) dengan pelaksanaan sebanyak dua siklus yang mencakup dari sejumlah tahapan yakni tahap perencanaan, tindakan, observasi dan refleksi. Sampel pada penelitian ini sebanyak 35 orang siswa, dengan masing-masing dari 13 orang siswa laki-laki maupun terdapat 22 orang siswa perempuan. Metode pengumpulan data yang digunakan adalah wawancara, observasi, angket, tes, dan dokumentasi. Penelitian ini menggunakan teknik analisis data deskriptif kuantitatif. Hasil penelitian menunjukkan bahwa penerapan media pembelajaran $Q R$ Code berbantuan Canva memudahkan siswa dalam mencari informasi, karena dapat terhubung langsung dengan link video, gambar, materi ajar yang akan diamati yang membuat siswa kreatif dan terampil dalam menyajikan laporan secara tertulis dalam bentuk resume melalui aplikasi canva sehingga meningkatkan hasil belajar ekonomi siswa kelas XII IPS 2 SMA Negeri 1 Besuki. Hal ini dibuktikan dengan meningkatnya hasil belajar siswa kelas XII IPS 2 SMA Negeri 1 Besuki sebelum diberikan tindakan rata-rata nilai siswa tergolong masih rendah dibandingkan setelah diberikan tindakan ketuntasan belajar siswa mengalami peningkatan sebesar $8,57 \%$. Berdasarkan data tersebut, maka dapat disimpulkan bahwa media pembelajaran $Q R$ Code berbantuan Canva sangat efektif dan efisien diterapkan dalam proses pembelajaran siswa.
\end{abstract}

Kata Kunci: akuntansi, canva, hasil belajar, QR code.

\section{APPLICATION OF CANVA-ASSISTED QR CODE LEARNING MEDIAS TO IMPROVE ACCOUNTING LEARNING RESULTS}

\begin{abstract}
This study aims to examine the application of Canva-assisted QR Code learning media in improving student learning outcomes for class XII IPS 2 SMA Negeri 1 Besuki in accounting subjects. This research is a classroom action research with the implementation of two cycles which includes a number of stages, namely the stages of planning, action, observation and reflection. The sample in this study were 35 students, with each of the 13 male students and 22 female students. Data collection methods used are interviews, observations, questionnaires, tests, and documentation. This study uses descriptive quantitative data analysis techniques. The results showed that the application of Canva-assisted QR Code learning media made it easier for students to find information, because it could be connected directly with video links, images, teaching materials to be observed which made students creative and skilled in presenting written reports in the form of resumes through the Canva application so that improve economic learning outcomes for students of class XII IPS 2 SMA Negeri 1 Besuki. This is evidenced by the increase in student learning outcomes of class XII IPS 2 SMA Negeri 1 Besuki before being given action, the average score of students is still low compared to after being given action, student learning completeness has increased by $8.57 \%$. Based on these data, it can be concluded that the QR Code learning media assisted by Canva is very effective and efficient to apply in the student learning process.
\end{abstract}

Keywords: accounting, canva, learning outcomes, $Q R$ code 


\section{PENDAHULUAN}

Era digitalisasi menuntut kita untuk bergerak cepat dalam menyongsong revolusi industri 4.0. Tantangan dan persaingan global semakin terbentang nyata di depan mata. Pembelajaran di abad 21 menuntut seorang pendidik untuk mengambil inisiatif terhadap langkah perubahan dengan mengubah paradigma pola belajar dari konvensional (teacher centered learning) menjadi pola pembelajaran baru dengan melibatkan siswa sebagai aktor utama dalam proses pembelajaran (student centered learning). Prinsipnya pada pembelajaran abad 21, guru sudah beralih peran yang dahulu hanya menjadi sumber pengetahuan dan mendominasi proses pembelajaran. Pembelajaran yang dimaksud tidak lagi menggunakan metode ceramah sebagai metode penyampaian informasi dan pengetahuan kepada siswa (tranfer of knowlegde). Setiap proses belajar, seorang guru hanya perlu bertindak layaknya fasilitator.

Perlu di ketahui bahwa guru perlu menjadi role model pembelajar (learner media) bagi siswanya. Perkembangan ilmu pengetahuan dan teknologi mesti di ikuti oleh guru. Era pendidikan yang telah memasuki era revolusi industri 4.0 mempunyai ciri pemanfaatan teknologi secara digital. Oleh karena itu guru yang baik harus dapat mengikuti perkembangan jaman melalui pemanfaatan yang ada dalam teknologi. Dengan demikian proses pembelajaran berlangsung secara cepat, efektif dan efisien tanpa batas ruang dan waktu.

Guru tidak memiliki pilihan lain dalam peningkatan profesionalitasnya di bidang penguasaan teknologi informasi. Upaya ini dilakukan supaya guru dapat mempersiapkan siswanya menjadi generasi emas yang unggul dan mampu beradaptasi di tengah era digital dengan kompetensi global yang semakin ketat. Diketahui jaman revolusi industri 4.0 telah mengharuskan adanya efisiensi, digitalisasi, dan otomatisasi, yang mendorong peluang emas untuk mereka yang dapat mengimplementasikan teknologi informasi dan komunikasi terutama dalam bidang pendidikan.

Hal ini sejalan dengan penyelenggaraan sistem pendidikan nasional dalam Ref. [1] terkait prinsip dalam menyelenggarakan pendidikan yang berbunyi: "Penyelenggaraan pendidikan perlu memberi keteladanan, membangun inisiatif, dan mengembangkan kreativitas siswa dalam proses belajar".

Salah satu upaya dalam meningkatkan jiwa inisiatif, mengembangkan kreativitas siswa dipandang perlu. Salah satu hal yang perlu diupayakan yaitu kemampuan guru dalam merancang, melaksanakan, dan mengelola proses pembelajaran. Proses pembelajaran yang diharapkan adalah interaksi belajar yang berlangsung secara menarik, kekinian, efisien, praktis dan tidak membosankan. Dengan demikian siswa menjadi lebih menarik, dimengerti, serta aktif dalam menemukan dan mencari sendiri. Oleh karena itu, guru perlu menjalin hubungan komunikasi bersama siswa dengan menentukan metode media dan media belajar yang tepat.

Sependapat dengan hal tersebut menurut Listyana dalam Ref. [2] ketika guru memilih dan menerapkan metode pengajaran yang tepat saat memberikan materi, diharapkan dapat meningkatkan keaktifan siswa dalam proses belajar mengajar, dan membantu siswa untuk menerima dan memahami materi dengan lebih mudah. Selain Oleh karena itu, untuk dapat merangsang daya pikir, kemampuan dan perhatian siswa adalah dengan memilih media pembelajaran yang menarik bagi siswa.

Namun tampaknya ketika aktivitas proses belajar akuntansi SMA Negeri 1 Besuki di kelas XII IPS 2 masih jauh dari kondisi ideal. Berdasarkan pengamatan peneliti, pada saat proses pembelajaran akuntansi berlangsung, nampak gejala-gejala belajar yang kurang baik seperti: 1) ekspresi wajah kebingungan karena rendahnya kemampuan dalam memahami konsep materi akuntansi, 2) nilai ulangan siswa kelas XII IPS 2 berada dibawah KKM dengan nilai rata-rata 40,25. Hal ini disebabkan kemampuan menganalisis dan menyelesaikan soal masih rendah, 3) hanya sebagaian siswa saja yang antusias (munculnya feed back) dan sebagian besar siswa pasif dalam mengikuti pelajaran (tidak adanya feed back), dan 4) adanya praktik mencontek pekerjaan teman yang pandai sebagai bentuk gugur kewajiban dari guru dalam bentuk pengerjaan tugas-tugas. 5) Hasil kuesioner danr wawancara secara terbuka dengan siswa XII IPS menunjukkan sebagian besar siswa XII IPS kurang respon dan menyatakan pelajaran akuntansi sulit.

Fenomena tersebut sesuai dengan pendapat Ciptaning dan Santoso pada Ref. [3] bahwa mata 
pelajaran IPS di sekolah mesti memperoleh perhatian serius. Pembelajaran IPS pada umumnya diterapkan hanya lewat buku dan guru menyampaikan materi sehingga siswa kurang memperoleh motivasi belajar. Dengan pemanfaatan QR-Code diharapkan motivasi belajar siswa meningkat. Penggunaan QR-Code di sekolah mampu memberi pengaruh yang cukup besar. Pertama, keterlibatan siswa lebih banyak. QR-Code membantu guru dalam berinteraksi bersama siswa serta mendorong siswa untuk belajar lebih banyak dan secara ringkas. Kedua, QR-Code mendorong perubahan terkait pengalaman belajar mengajar menjadi tempat belajar yang interakif \& menyenangkan.

Ciptaning dan Santoso dalam Ref. [3] menyatakan bahwa proses belajar discovery learning dengan bantuan QR-Code mampu membawa peningkatan terhadap proses sains dari peserta didik, yang tercakup: 1) peningkatan pengamatan sebesar $14,14 \%$, ;2) peningkatan komunikasi sebesar $21,21 \%, ; 3)$ peningkatan klasifikasi sebesar $10,11 \%$, dan kesimpulan sebanyak 29,3\%.

Adapun penelitian yang dilakukan Farida dan Hasanudin dalam Ref. [4] menyimpulkan bahwa melalui penerapan Problem Based Learning (PBL) dengan QR-Code mampu terjadi peningkatan terhadap hasil belajar matematika siswa kelas X MIPA 3 SMAN 1 Kotagajah. Hal tersebut dibuktikan berdasarkan dari data persentase nilai dari siklus I mencapai $47,22 \%$ serta dari siklus II mengalami peningkatan sebanyak $63,89 \%$.

Kusumaningtyas dan Hakim pada Ref. [5] menyimpulkan bahwa Mengembangkan buku teks metode ilmiah berbasis kode QR dan mengintegrasikan kahoot ke dalam topik layanan lembaga keuangan syariah di SMK XI semester 1 yang sangat sesuai untuk menunjang proses pembelajaran. Respon siswa terhadap isi dan kinerja mencapai 97,31\%. Artinya setelah pembelajaran menggunakan bahan ajar yang dikembangkan, siswa tertarik dengan kegiatan pembelajaran kode dua dimensi dan penerapan tes kahoot inovatif.

Sependapat dalam hasil penelitian Fauziah dan Djazarid dalam Ref. [6] bahwa media pembelajaran berbasis QR Code pada mahasiswa jurusan akuntansi terbukti mengalami peningkatan motivasi belajar jurnal penutup siswa kelas XII IPS SMA Negeri 2 Bantul mencapai 4,23\% dari hasil tersebut diperoleh persentase hasil rerata sesudah motivasi dikurangi dan sebelum adanya hasil persentase rerata motivasi.

Berdasarkan kondisi tersebut, peneliti memandang perlu adanya upaya untuk mampu mengalami peningkatan terhadap hasil belajar akuntansi XII IPS 2 siswa SMA Negeri 1 Besuki. Dalam hal ini guru dianggap bertanggung jawab atas keberhasilan proses pembelajaran. Adapun upaya yang dapat dilaksanakan yaitu dengan merancang dan menyiapkan materi dan bahan ajar serta menyiapkan metode, media dan media pembelajaran yang dicanangkan mampu mendorong siswa dalam minat belajarnya yaitu melalui penerapan teknologi digital QR Code berbantuan Canva.

Rumusan masalah dalam penelitian ini yaitu untuk memahami bagaimanakah proses meningkatkan hasil belajar akuntansi siswa kelas XII IPS 2 SMA Negeri 1 Besuki melalui media QR Code berbantuan Canva. Adapun tujuan peneliti menerapkan penelitian tindakan kelas yaitu dengan tujuan mengetahui bagaimana implementasi media belajar QR Code berbantuan Canva terhadap hasil belajar akuntansi siswa kelas XII IPS 2 SMA Negeri 1 mengalami peningkatan.

\section{METODE PENELITIAN}

Penelitian ini menggunakan pendekatan penelitian tindakan kelas/classroom action research (PTK) dengan II siklus [7]. Siklus pada penelitian tindakan kelas yang dipakai adalah media Kurt Lewin [8]. Rancangan setiap siklus mencakup empat bagian tahapan yakni: 1) perencanaan (planning), 2) tindakan (acting), 3) pengamatan (observing), dan 4) refleksi (reflecting). Media penelitian yang dimaksud digambarkan dengan skema berikut ini.

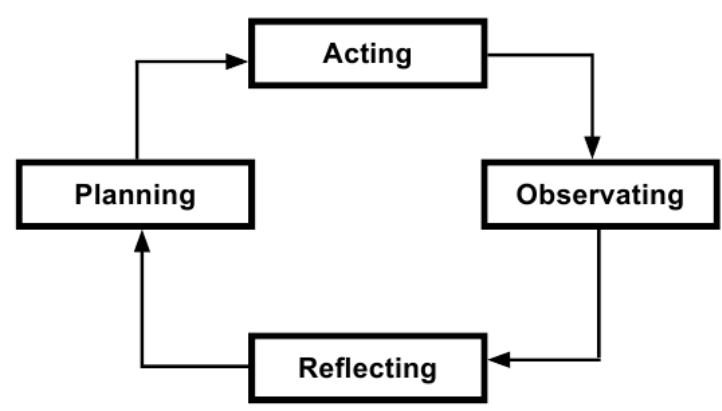

Gambar 1. Siklus Pada Penelitian Tindakan Kelas

Lokasi pelaksanaan penelitian berada di SMA Negeri 1 Besuki, di semester ganjil tahun ajaran 2019-2020. Subyek penelitiannya adalah siswa kelas 
XII IPS 2 sebanyak 35 orang, dengan masing-masing dari 13 orang siswa laki-laki maupun terdapat 22 orang siswa perempuan. Waktu pelaksanaan dimulai bulan September-November 2019. Kompetensi dasar 3.5 yakni melakukan analisis siklus terhadap akuntansi perusahaan jasa, 4.5 melakukan praktik siklus pada akuntansi perusahaan jasa dan materi yang meliputi: 1) penyusunan siklus akuntansi pada akuntansi perusahaan jasa pada siklus I, dan 2) tahapan penutupan pada akuntansi perusahaan jasa di siklus II

Penelitian ini menggunakan teknik pengumpulan data berupa instrumen/alat yang dipakai dalam memperoleh data penelitian seperti, lembar observasi proses belajar siswa, lembar observasi guru, lembar angket, lembar kerja peserta didik (LKPD), daftar pertanyaan untuk wawancara, dan dokumentasi. Sedangkan analisis deskriptif kuantitatif dipakai untuk analisis data penelitian ini.

Rancangan sebelum eksperimen penelitian menggunakan the one shot case study. Penelitian cuma menggunakan satu kelompok atau kejadian dalam waktu periode tertentu, kelompok lain tidak dilibatkan untuk menjadi kontrol terhadap kelompok eksperimen sebagai bandingan dari kelompok eksperimen. Dikutip dari Ref. [9] yang menuliskan "Perlakuan diberikan untuk permulaan sehingga dalam mengetahui hasil yang diperoleh dari pelaksanaan dipenghujung kegiatan atau kejadian". Rancangan pre eksperimen yang dimaksud tercantum pada gambar berikut ini.

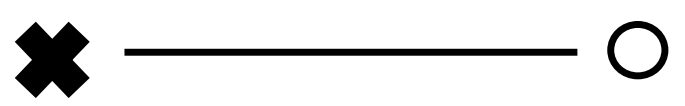

Perlakuan Posttest

Gambar 2. Rancangan pre eksperimen the one shot case study

Perencanaan tahap siklus I meliputi: 1) menyiapkan dan merancang bahan ajar dan LKS (lembar kerja siswa), 2) menyusun RPP, 3) menyiapkan bahan latihan konsep/soal, 4) membuat lembar observasi, dan 5) menyiapkan tes evaluasi siklus I. Pelaksanaan tindakan mengikuti sintaks yang disusun dalam RPP. Adapun kompetensi dasar yang disasar pada siklus I adalah penyusunan siklus akuntansi pada perusahaan jasa. Demikian halnya dengan pengamatan, peneliti mengamati proses pelaksanaan tindakan penelitian. Di akhir kegiatan siklus I, test diberikan ke siswa. Hasil pengamatan pada dan hasil test pada siklus I dijadikan bahan refleksi pada perencanaan siklus II.

Siklus II sama dengan siklus I terkait dalam perencanaan tindakan namun kompetensi dasar yang digunakan berbeda yaitu tahapan penyusunan siklus akuntansi pada perusahaan jasa. Berdasarkan refleksi dalam siklus I, peneliti memperbaiki atau menekan terhadap pelaksanaan pembelajaran dari ketidak efektifannya. Hal-hal yang dianggap menganggu jalannya proses pembelajaran diminimalisir dengan lebih memberdayakan keaktifan siswa. Selanjutnya di akhir kegiatan siklus II, siswa diberikan test.

Tahap pelaksanaan tindakan dalam siklus I dilaksanakan sesuai proses sintaks pembelajaran Discovery Learning. Dimulai dari kegiatan awal, kegiatan inti, hingga terakhir adalah penutup. Dalam kegiatan ini pendahuluan diterapkan melalui pola sebagai berikut: 1) salam, berdoa, presensi, 2) mengondisikan kelas, 3) mempersiapkan media serta alat maupun buku/sumber belajar, 4) penghargaan, 5) penyampaian tujuan pembelajaran dan kompetensi dasar, 6) menyampaikan lingkup, teknik penilaian, metode dan media pembelajaran QR Code berbantuan canva, dan 7) 4-5 siswa dibentuk menjadi sebuah kelompok. Memasuki kegiatan inti dilakukan melalui tahapan sebagai berikut: 1) memberikan stimulus, 2) pengidentifikasi masalah, 3) pengumpulan data, 4) olah data, 5) melakukan verifikasi, dan 6) penyimpulan. Kemudian kegiatan pembelajaran tahap akhir adalah kegiatan penutup. Kegiatan penutup dilakukan melalui tahap-tahap seperti berikut: 1) refleksi kegiatan yang telah dilakukan, 2) siswa diminta untuk mengumpulkan lembar kerja hasil diskusi kelompok, 3) Penugasan mandiri secara individu maupun kelompok, 4) Guru menyampaikan rencana pembelajaran pada pertemuan kedepannya, dan 5) salam untuk menutup pelajaran. Begitu pula halnya dengan pelaksanaan tindakan pada siklus II, sintaks pembelajaran mengikuti langkah-langkah pelaksanaan pembelajaran pada siklus I.

Selanjutnya tahap pengamatan (observing) dilakukan dengan pengamatan dengan berkolaborasi dengan guru lain (observer) untuk mengamati proses pembelajaran. Berdasarkan hasil observasi, dapat diketahui keaktifan dan cara kerja siswa dalam kelompok, dan kekurangan guru dalam proses pembelajaran. Tahapan selanjutnya adalah melakukan refleksi. Refleksi dilakukan dengan 
rencana tindak lanjut pada siklus II yang berupa evaluasi atas penemuan kekurangan dalam siklus I.

\section{HASIL PENELITIAN}

Keberadaan teknologi digital sangat akrab dalam kehidupan kita sehari-hari. Perangkat komunikasi elektronik seperti smartphone dan android bukan merupakan hal baru lagi. Hampir semua siswa di SMA Negeri 1 Besuki menggunakannya. Dalam hal ini pihak sekolah memperbolehkan menggunakan, selama penggunaannya bersifat positif dan mendukung kelancaran proses pembelajaran seperti menggali informasi melalui internet. Namun demikian, dalam mencari informasi dari internet, siswa membutuhkan waktu yang lama dalam memilih informasi yang tepat sehingga proses pembelajarannya. Adakalanya terjadi penyimpangan perilaku pada siswa, beberapa siswa tidak bersungguh-sungguh dalam mencari informasi, akan tetapi melakukan browsing internet yang tidak ada kaitannya dengan materi yang dipelajari.

QR Code adalah Quick Response Code, Pada mulanya aplikasi tersebut dikembangkan oleh bangsa Jepang untuk keperluan industri otomotif. Tuntutan saat itu adalah pembuatan kode yang dapat menyimpan data/informasi dan dapat dibaca/diterjemahkan secara cepat dan akurat. Saat ini, penggunaan QR Code ini sudah sangat luas, Tidak hanya digunakan untuk kepentingan di dunia industri, namun juga dapat digunakan dalam dunia pendidikan. McNiff dalam Ref. [10] menyatakan pemanfaatan smartphone terhadap pembelajaran salah satunya dengan menginstal aplikasi Quick Respon Code (QR Code).

Dalam penggunaan QR Code, dibutuhkan alat pembaca/pemindai barcode yang disebut QR Code Reader/Scanner. Alat ini adalah aplikasi yang bisa diunduh dari playstore serta diinstall pada smartphone atau android. Cara pemindaian QR Code sangat mudah. Adapun langkah pemindaian berupa: 1) membuka aplikasi pembaca/pemindai QR Code,2) arahkan pada QR Code yang akan dipindai. Setelah aplikasi membaca kode, secara otomatis akan terkoneksi dengan internet dan membuka browser situs, web, link video, gambar. Adapun bentuk QR Code bisa dilihat seperti berikut ini.

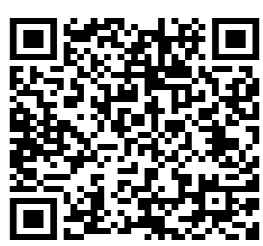

Gambar 3. Tampilan QR Code

Muri Yusuf pada Ref. [11] berpendapat untuk membuat desain kegiatan belajar yang menarik. Terdapat suatu aplikasi yang relevan sebagai alternatif yaitu Canva. Aplikasi canva dapat diakses secara gratis maupun berbayar berbasis internet yang praktis diakses khususnya untuk memanfaatkan fitur tersebut dalam membuat rancangan media belajar.

Sedangkan canva merupakan aplikasi desain online yang dapat digunakan di PC, laptop, smartphone atau android. Adapun keunggulannya, aplikasi ini menyediakan banyak desain yang dapat dibuat dengan mudah dan praktis. Layanan ini dapat diandalkan untuk membuat desain poster, infografis, resume, dokumen. Aplikasi ini sangat cocok bagi generasi milineal yang lekat dengan media sosial. Cara kerjanya sangat sederhana, dan mampu diakses dengan mudah tanpa mengenal waktu dan tempat secara seketika.

Menurut Rahmayanti dan Jaya pada Ref. [12] sebagai aplikasi berbasis teknologi, Canva menyediakan ruang belajar untuk setiap guru dalam melaksanakan suatu pembelajaran dengan mengandalkan media pembelajaran. Media yang menyediakan lebih banyak desain template menarik agar peserta didik di saat pembelajaran merasa tertarik terhadap media.

Adapun cara menggunakan aplikasi canva sebagai berikut: 1) mendaftar untuk mendapatkan akun dalam aplikasi canva, 2) masuk ke dahsboard canva, 3) menentukan bentuk desain, 4) mengedit desain, dan 5) mendowload desain. Dengan menerapkan penggabungan dua teknologi digital ini, maka penerapan media pembelajaran QR Code berbantuan canva ini diharapkan dapat meningkatkan hasil belajar akuntansi siswa kelas XII IPS 2 SMA Negeri 1 Besuki.

Aplikasi Canva bisa meningkatkan siswa untuk lebih kreatif serta terampil untuk menyajikan hasil diskusi kelompoknya secara tertulis. Adapun contoh desain tampilan resume diskusi kelompok dapat dilihat sebagai berikut. 


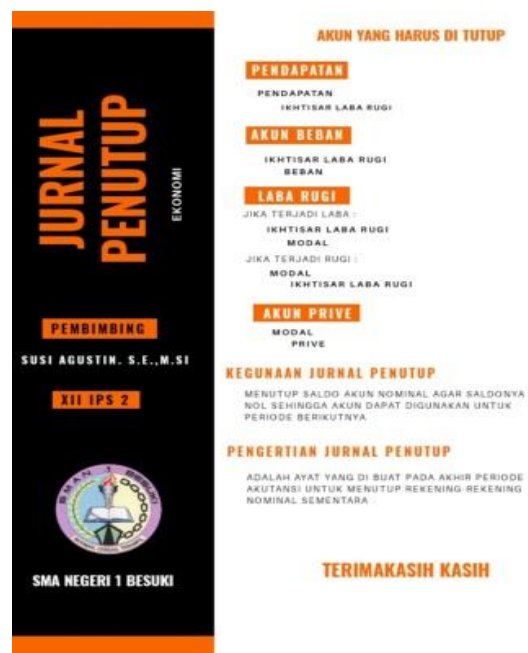

Gambar 4. Tampilan Resume Hasil Diskusi Siswa

Pengkomunikasian adalah kegiatan siswa untuk memaparkan informsi hasil temuan mereka yang dimuat dalam bentuk gambar maupun tabel [16]. Keterampilan bekerja, bersikap ilmiah, dan berpikir serta melakukan komunikasi guna mengikuti aspek penting terhadap kecakapan hidup pada abad 21 . Dalam penerapan media belajar $Q R$ Code berbantuan Canva ini, siswa dapat menyajikan hasil diskusi kelompok dalam bentuk tampilan resume yang singkat, padat, dan menarik.

Penggunaan media ini untuk menjawab permasalahan belajar yang muncul pada siswa. Selama ini pendapat yang muncul di kalangan siswa, akuntansi merupakan mata pelajaran yang sulit dan membingungkan [13]. Sebagai seorang guru, dan sekaligus peneliti menyadari bahwa tidak sepenuhnya kemampuan belajar siswa itu sama. Hal ini sejalan dengan pendapat Heri dalam Ref. [14] yang menyebutkan adanya empat tipe kemampuan anak dalam menyerap informasi pelajaran, sebagai berikut: 1) tipe pembelajar cepat (fast learner), yaitu anak dengan kategori pembelajar yang sangat mudah memahami pengetahuan yang diinformasikan, 2) tipe pembelajar normal (normaly learner), yaitu anak yang membutuhkan sekali sampai tiga kali pengulangan materi agar dapat memahami konsep, 3) tipe pembelajar lambat (slow learner), yaitu anak yang membutuhkan waktu pengulangan 3 sampai 6 kali untuk dapat memahami konsep. Respon anak sangat lambat dalam menyerah dan mengolah informasi, 4) pembelajar sangat lambat (very slow learner) yaitu anak dengan kategori berkebutuhan khusus baik secara fisik maupun psikis. Demikian juga halnya dengan kondisi siswa kelas XII IPS 2 SMA Negeri 1 Besuki. Secara umum karakteristik siswa di kelas tersebut merupakan tipe pembelajar normal (normaly learner) dengan skor IQ antara 90 100, dan tipe pembelajar lambat (slow learner) dengan skor IQ antara 70-89. Fakta ini teridentifikasi dari hasil test IQ yang dilaksanakan oleh sekolah. Peneliti melakukan kolaborasi dengan BK dalam menganalisa data tersebut. Disamping itu, data tersebut juga disandingkan dengan nilai ulangan harian akuntansi yang dicapai oleh siswa dengan nilai rerata jauh dari kriteria ketuntasan minimal (KKM).

Chatib mengemukakan dalam Ref. [15] salah satu permasalahan yang masih sering dihadapi oleh dunia pendidikan Indonesia adalah lemahnya kemampuan belajar guru. Hal ini senada dengan pendapat Bapak Nadim Makarim, Menteri Pendidikan dan Kebudayaan Republik Indonesia, bahwa masalah mendasar pendidikan terletak pada ruang kelas, yaitu apa yang terjadi antara siswa dan guru. Siswa kurang terdorong untuk belajar secara aktif, sehingga pembelajaran di kelas hanya ditujukan pada kemampuan siswa dalam menghafal pelajaran. Guru hanya mengajar melalui ceramah dan latihan.

Kondisi siswa setelah memperoleh hasil belajar sebelum diberi tindakan menunjukkan hasil di peroleh kurang memuaskan. Hasil nilai test siswa untuk mencapai kriteria ketuntasan minimal (KKM) dengan jumlah 3 orang adapun rerata nilai dalam kelas sebesar 40,5. Situasi belajar menunjukkan gejala-gejala yang tidak ideal seperti aktivitas belajar siswa yang pasif, ekspresi kebingungan, tidak ada umpan balik. Berdasarkan kondisi tersebut, maka peneliti melakukan upaya perbaikan proses pembelajaran dengan memanfaatkan penggunaan media pembelajaran QR Code berbantuan Canva terhadap mata pelajaran akuntansi kelas XII IPS 2 siswa SMA Negeri 1 Besuki dalam peningkatan hasil belajar

Pelaksanaan untuk siklus I, ditemukan siswa antusias dan aktif dengan media pembelajaran baru. Suasana belajar menjadi lebih hidup, menyenangkan, dan mendorong rasa ingin tahu siswa tercakup dalam gambar 3 berikut. 


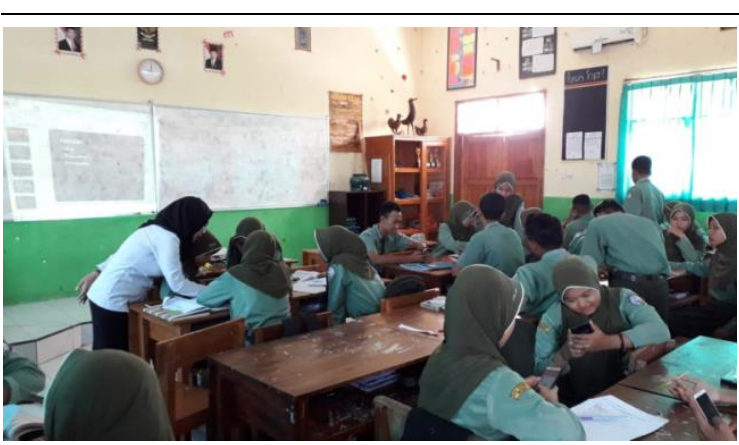

Gambar 5. Suasana Belajar di Kelas XII IPS 2 untuk Siklus I

Berdasarkan temuan diatas terdapat mayoritas siswa (86\%) mengatakan tidak mengalami kesulitan dalam menggunakan aplikasi kode QR, 91\% siswa dapat menggunakannya secara individu atau kelompok, dan $86 \%$ siswa percaya bahwa mereka lebih mandiri dalam belajar dan dapat terus mengulangi bahan yang disediakan tanpa hambatan [9].

Guru membutuhkan media pembelajaran untuk dapat meningkatkan kreativitas guru dalam mempersiapkan media belajar yang mendorong minat belajar peserta didik dari materi yang disampaikan [10]. Maka, peneliti menerapkan media pembelajaran canva.

Hasil temuan dalam siklus I mulai meningkatkan hasil belajar terhadap nilai test yang mencukupi dari kriteria ketuntasan minimal (KKM) yang terdiri 27 orang dengan rerata nilai 75,1 . Namun ada hal yang perlu diperbaiki, sebagian siswa lebih fokus pada praktik cara menggunakan aplikasi baru pada android mereka, dan sebagian lainnya fokus pada penguasaan konsep materi yaitu penyusunan siklus akuntansi pada perusahaan jasa. Berdasarkan hasil observasi pengamat (observer), guru belum dapat mengalokasikan waktu pembelajaran dengan baik, sehingga pembelajaran terkesan terburu-buru pada kegiatan akhir yaitu menyajikan kesimpulan dan rencana pembelajaran berikutnya.

Tahapan dalam siklus II, perbaikan dilakukan oleh peneliti proses pembelajaran melalui penekanan untuk mengoptimalkan konsep materi ajar, dan memperbaiki pengalokasian waktu dalam proses pembelajaran secara efisien dan efektif. Upaya yang ditempuh yaitu memfasilitasi terjalinnya kerja sama dan diskusi di dalam kelompok menjadi lebih dinamis. Peneliti memberikan penguatan-penguatan berupa apreasiasi berupa tepuk tangan, acungan jempol, dan kata-kata penyemangat lainnya. Penelti juga memberikan rambu-rambu alokasi waktu pembelajaran kepada peserta didik.

Strategi yang dibangun supaya penguasaan konsep lebih kuat, dilakukan dengan cara melakukan latihan pengerjaan soal. Hal tersebut berdasarkan hasil penelitian dari pendapat Chatib dalam Ref. [15] mengemukakan bahwa siswa eksplorasi (activity) yakni aktivitas diskusi dalam kelas berupa temuan konsep ketika melakukan eksplorasi (class discussion), serta memantapkan konsep melalui pelatihan untuk mengerjakan tugas-tugas atau soalsoal latihan dari aplikasi yang telah diberikan. Dengan adanya perbaikan dalam siklus II, hasil belajar siswa untuk siklus II terlihat semakin meningkat dari sebelumnya. Hal tersebut terbukti melalui nilai test siswa yang telah mencukupi kriteria ketuntasan minimal (KKM) dengan jumlah 31 orang melalui nilai rerata 81,94 .

Pada akhir pelaksanaan antara siklus I hingga Siklus II, guru memberikan lembar angket respon siswa bagi penerapan media belajar berbasis QR Code melalui media Canva serta proses kegiatan pembelajaran secara keseluruhan. Pengambilan data tentang respon siswa terhadap proses pembelajaran juga dilaksanakan dengan teknik wawancara dan dokumentasi. Kemudian hasil proses pengambilan data respon siswa diperoleh dengan triangulasi..

Hasil setelah melakukan penelitian diperoleh data terkait nilai siswa sebelum melakukan tindakan dari siklus I hingga siklus II terlihat adanya peningkatan nilai oleh siswa. Dibuktikan berdasarkan hasil tes sebelum mengikuti kegiatan nilai rata-rata test yakni 40,5. Siklus I guru memberikan materi penyusunan siklus akuntansi pada perusahaan jasa sebanyak 8 pertemuan pembagian waktu untuk tiap pertemuan yakni 2 x 45 menit, dan didapatkan hasil belajar siswa dengan rerata pada test siklus I sebesar 75,1. Dengan penerapan media pembelajaran $\mathrm{QR}$ code berbantuan canva, pada siklus I sebesar $85,4 \%$ sehingga dapat disimpulkan adanya peningkatan terhadap pemahaman siswa. Walaupun secara signifikan melalui capaian ketuntasan belajar siswa, ada beberapa kelemahan yang tampak menurut hasil pengamatan pengamat (observer) seperti: 1) terdapat sejumlah siswa terlihat tidak aktif melakukan aktivitas belajar kelompok, 2) pengalokasian waktu belajar dari guru belum bisa tersusun dengan baik, 
dan 3) penguasaan konsep atas materi yang diajarkan perlu diperkuat dengan latihan soal.

Pada siklus II diajarkan materi tahapan penutupan siklus akuntansi pada perusahaan jasa sebanyak 8 pertemuan melalui alokasi waktu yang sama pada siklus I. Adapun hasil belajar dalam siklus II ditunjukkan dengan didapatkannya nilai pada tabel 1. Rata-rata test siswa sebesar 81,9 . Terhadap siklus II terlihat hasil belajar siswa meningkat menjadi $14,8 \%$.

Skor kriteria ketuntasan minimal (KKM) sebesar 70, pada saat sebelum tindakan nilai ketuntasan belajar siswa mencapai $8,6 \%$, untuk siklus I ketuntasan belajar yang diperoleh mengalami peningkatan sebesar 68,5\%, dan selanjutnya ketuntasan belajar siswa mengalami peningkatan $(88,6 \%)$ terhadap siklus II. Melalui perolehan rerata nilai ketuntasan yang mengalami peningkatan cukup signifikan, peneliti merasa puas karena target yang diharapkan mampu terpenuhi sehingga penelitian dimaksimalkan hingga tahapan siklus II saja. Di samping itu, kondisi kelas untuk lebih interaktif dan lebih bersemangat. Terlihat antusiasme siswa dalam mengikuti pelajaran dan feed back yang diberikan oleh siswa kepada guru lebih nampak.

Adapun perbandingan hasil belajar sebelum melakukan tindakan, siklus I, serta siklus II tercantum dalam tabel 1. Berikut ini:

Tabel 1. Perbandingan Nilai Hasil Belajar Siswa

\begin{tabular}{lccc} 
Keterangan & $\begin{array}{c}\text { Sebelum } \\
\text { Tindakan }\end{array}$ & Siklus I & Siklus II \\
\hline Rata-rata & 40,5 & 75,1 & 81,9 \\
\hline Skor Maksimal & 75 & 90 & 95 \\
\hline Skor Minimal & 20 & 40 & 50 \\
\hline $\begin{array}{l}\% \text { Ketuntasan } \\
\text { Siswa }\end{array}$ & $8,6 \%$ & $77,1 \%$ & $88,6 \%$ \\
\end{tabular}

Berdasarkan hasil analisis dapat diperoleh data, yaitu sebelum tindakan, siswa yang memperoleh nilai ketuntasan minimal berjumlah 3 orang. Sedangkan siswa belum memenuhi standar ketuntasan minimal sejumlah 32 orang siswa. Selanjutnya tahap siklus II, sebanyak 31 siswa mencapai kriteria ketuntasan minimal (KKM). Sedangkan terdapat 4 siswa atau dengan persentase $11,4 \%$ yang belum memenuhi kriteria ketuntasan minimal (KKM).

Peningkatan terjadi karena penerapan media pembelajaran $Q R$ Code berbantuan Canva meningkatkan minat siswa dalam mengikuti pembelajaran, serta terlihat siswa berpartisiasi secara aktif dan kreatif selama proses pembelajaran. Dengan adanya peningkatan minat belajar dan respon positif dari siswa, berpengaruh terhadap hasil belajar yang di peroleh oleh siswa. Penerapan media $Q R$ Code memudahkan siswa dalam mencari informasi, karena dapat terhubung langsung dengan link video, gambar, materi ajar yang akan diamati. Dalam hal ini penggunaan waktu menjadi lebih efisien. Begitu pula dengan penggunaan aplikasi Canva dalam proses pembelajaran.

Peneliti menarik kesimpulan berdasarkan analisis yang dihasilkan melalui data hasil observasi dan juga hasil tes bahwa penerapan media pembelajaran $Q R$ Code berbantuan Canva terhadap pembelajaran terhadap hasil belajar akuntansi siswa XII IPS 2 SMA Negeri 1 Besuki mengalami peningkatan. Hasil yang diperoleh siswa pada mata pelajaran akuntansi kelas XII IPS 2 melalui media pembelajaran berbasis $Q R$ Code berbantuan Canva cukup signifikan jika dilihat dari sebelum diterapkannya proses belajar tanpa adanya media pembelajaran $Q R$ Code berbantuan canva.

\section{KESIMPULAN}

Hasil analisis yang telah dilakukan menarik suatu kesimpulan terkait media pembelajaran $Q R$ Code berbantuan Canva sangat efektif dan efisien diterapkan dalam proses pembelajaran siswa XII IPS sehingga terjadi peningkatan hasil belajar mata pelajaran akuntansi. Dibuktikan melalui nilai test, siswa mampu memenuhi kriteria ketuntasan minimal (KKM) minimal 70. Hal tersebut dibuktikan dengan membandingkan hasil belajar siswa, sebelum dilakukannya siklus I hingga siklus II. Hasil belajar memperoleh sebuah peningkatan signifikan terkait rata-rata nilai siswa. Dapat diketahui nilai test ratarata siswa sebelum tindakan sebesar 40,5, dalam siklus I memperlihatkan nilai test rata-rata mencapai 75,1 , selanjutnya untuk siklus II dengan nilai test sudah mencapai rata-rata 81,9 .

Penerapan media pembelajaran $Q R$ Code berbantuan Canva di nilai mampu meningkatkan hasil belajar (ranah keterampilan). Peserta didik menjadi kreatif serta terampil dalam menyajikan laporan secara tertulis dalam bentuk resume dengan desain yang menarik melalui aplikasi Canva. Penilaian keterampilan siswa didapatkan dari kreatifitas mendesain resume. 
Berdasarkan hasil analisis penelitian, pihak sekolah dapat memfasilitasi guru untuk mengajar dengan menggunakan berbagai media pembelajaran yang sesuai dan tepat terhadap materi belajar, sehingga terjadi keefektifan dan efisiensi dalam proses pembelajaran. Salah satunya melalui penerapan media pembelajaran QR Code berbantuan Canva sebagai alternatif media pembelajaran mampu diterapkan pada mata pelajaran lainnya. Selain itu guru juga harus dapat mengembangkan kreativitasnya untuk menemukan media pembelajaran lain berbasis teknologi yang mampu meningkatkan hasil belajar siswa agar tujuan pembelajaran bisa tercapai secara efektif $\&$ efisien.

\section{DAFTAR PUSTAKA}

[1] P. R. Indonesia, Undang-undang Republik Indonesia nomor 20 tahun 2003 tentang sistem pendidikan nasional. Departemen Pendidikan Nasional, 2003.

[2] J. \& S. Herawati Gladis Ani Sadewi Listyana, "Peningkatan Aktivitas Dan Hasil Belajar Akuntansi Keuangan Melalui Penerapan Media Pembelajaran Reciprocal Teaching Berbantu Mind Map.," J. Tata Arta, Univ. Sebel. Maret, vol. 4 (1), 2018.

[3] L. A. Ciptaning, Santoso, "Implementasi Pembelajaran Discovery Learning Berbantuan QR-Code Untuk Meningkatkan Keterampilan Proses Sains," J. Pendidik. Biol. Muhammadiyah Metro., vol. 9 (2), 2018.

[4] N. S. Farida, Hasanudin, "Problem Based Learning (PBL) - QR-Code dalam Peningkatan Hasil Belajar Matematika Peserta Didik," J. Pendidik. Mat. Univ. Muhammadiyah Metro, vol. 8 (1), 2019.

[5] H. N. Kusumaningtyas and L. Hakim, "Pengembangan Buku Scientific Approach Berbasis QR Code Berintegrasi Kahoot," $J$. Pendidik. Ekon., vol. 13, no. 2, pp. 84-93, 2020.

[6] D. Fauziah and M. Djazari, "pengembangan media pembelajaran qr card akuntansi untuk meningkatkan motivasi belajar jurnal penutup siswa kelas xii ips sma negeri 2 bantul tahun pelajaran 2018/2019,"J. Pendidik. Akun, vol.
16, no. 2, pp. 99-112, 2018.

[7] D. Nafisah and A. Ghofur, "Pengembangan Media Pembelajaran Scan Barcode Berbasis Android Dalam Pembelajaran IPS," J. Edutek Pemb. Univ. PGRI Adi Buana, vol. 1, no. 2, 2020.

[8] D. Yudhistira, Menulis Penelitian Tindakan Kelas Yang Apik. Gramedia Widiasarana Indonesia, 2013.

[9] J. McNiff, Action research: Principles and practice. Routledge, 2013.

[10] A. Muri Yusuf, Metode penelitian kuantitatif, kualitatif \& penelitian gabungan, Prenada Me. 2016.

[11] A. Saleh, N. Saud, S., "Pemanfaatan QR-Code sebagai media pembelajaran Bahasa Asing pada Perguruan Tinggi di Indonesia,” 2019.

[12] D. Rahmayanti and P. Jaya, "Pengaruh Penerapan Media Pembelajaran Canva dengan Pendekatan Saintifik Terhadap Hasil Belajar dasar Listrik dan Elektronika," VoteTEKNIKA J. Vocat. Tek. Elektron. dan Inform., vol. 8, no. 4, pp. 107-113, 2020.

[13] G. Pelangi, "Pemanfaatan Aplikasi Canva Sebagai Media Pembelajaran Bahasa Dan Sastra Indonesia Jenjang SMA/MA” J. Sasindo UNPAM, vol. 8, no. 2, pp. 79-96, 2020.

[14] Heri, Akuntansi Untuk SMK, SMA, \& MA, Grasindo. Jakarta, 2014.

[15] A. S. Chatib, Munif, Sekolah Anak-anak Juara Berbasis Kecerdasan Jamak dan Pendidikan Berkeadilan. Bandung: Mizan Pustaka, 2012.

[16] M. Nashiroh and S. Sukirno, "Peningkatan Aktivitas Dan Hasil Belajar Akuntansi Melalui Implementasi Media Pembelajaran Kooperatif Teams Games Tournament" J. Pendidik. Akunt. Indones., vol. 18, no. 1, pp. 20-35, 2020.

[17] A. A. Zamista and I. Kaniawati, "Pengaruh media pembelajaran process oriented guided inquiry learning terhadap keterampilan proses 
sains dan kemampuan kognitif siswa pada mata pelajaran fisika," Edusains, vol. 7, no. 2, pp. 191-201, 2015.

[18] M. Purwadi, S. Akbar, "Strategi Pembelajaran Guided Inquiry Melalui Practice Rehearsel Pairs Pada Pembelajaran IPA Kelas IV Sekolah Dasar," 2016.

[19] T. Siim, " Cara Menggunakan Kode QR untuk Sekolah dan Pendidikan" Pageloot.com,https://pageloot.com/id/kode-qruntuk/sekolah-dan-pendidikan, 2020. 